\title{
SYNTHESIS, SPECTRAL CHARACTERIZATION, ANTIMICROBIAL, ANTI-INFLAMMATORY, ANTIOXIDANT, AND CYCLIC VOLTAMMETRIC STUDIES OF $\beta$-DIKETONE AND ITS METAL COMPLEXES
}

\author{
Narendra A. Bhise, Sultan. A. Al-horaibi, Suresh T. Gaikwad \\ and Anjali S. Rajbhoj* \\ ${ }^{1}$ Department of Chemistry, Dr. Babasaheb Ambedkar Marathwada University Aurangabad \\ 431004 (Maharashtra) India. \\ *E-mail : anjali.rajbhoj@gmail.com
}

\begin{abstract}
$\beta$-diketone and its five transition metal complexes with stoichiometry $\left[\mathrm{M}(\mathrm{L})_{2}\left(\mathrm{H}_{2} \mathrm{O}\right)_{2}\right][\mathrm{M}=\mathrm{Mn}(\mathbf{1}), \mathrm{Fe}(\mathbf{2}), \mathrm{Co}(\mathbf{3}), \mathrm{Ni}$ (4) and $\mathrm{Cu}$ (5); [L= 3-hydroxy-3-(2-hydroxyphenyl)-1-(2-iodo-5-methyl phenyl)prop-2-en-1-one] has been prepared. Ligand (L) was obtained by the well-known Baker-Venkataraman transformation. $\beta$-diketones exist in the intramolecular hydrogen bonded keto-enol tautomerism hence form a metal chelate, as an enolic hydrogen atom can be replaced by metal and ketonic oxygen, thereby completing the chelate ring, hence act as a chelating in the preparation of metal complexes. The synthesized compound has been characterized by NMR, IR, LC-MS and elemental analysis. Solution conductivity and electrochemical behavior were also studied by cyclic voltammetry. The synthesized compounds were screened in vitro for their antibacterial, antioxidant and anti-inflammatory activities, it is observed that complexation led to a remarkable increase in activities.

Keywords: Baker-Venkataraman, $\beta$-diketones, antibacterial, antioxidant, anti-inflammatory, cyclic voltammetry.

@ $\mathrm{R} A \bar{S} \bar{Y} Y A N$. All rights reserved
\end{abstract}

\section{INTRODUCTION}

Coordination chemistry is applicable in almost every field of life. Coordination compounds or transition metal complexes play a vital role in nature as exemplified by the function of macromolecules such as hemoglobin, chlorophyll, etc. that regulate various enzymatic processes in biological systems. Many enzymes contain coordinated metal ions as their active center. Metal-containing compounds are also important in the process of energy transfer. Therefore, studies on metal complexes, have always been a subject of interest, intrigue and challenge to the chemist, particularly to the inorganic chemist. A survey of current literature in this field reveals that synthetic coordination chemistry has advanced so much as to be able to produce complexes that mimic and therefore challenge biological systems in terms of energy capture. ${ }^{1,2}$ The coordination chemistry of the complexes involving 1,3-diketone ligands having two $\mathrm{O}$ donor groups and a number of metal ions has become an area of much focus due to the versatility of 1,3diketone ligands. ${ }^{3}$ 1,3-diketone on treating with transition metal ions produces complexes, which have been widely employed in material science and medicine. $\beta$-diketones has much industrial and medicinal application hence widely used, it possesses unique structural features and chemical functionalities and toughness for light and heat as electroluminescence. ${ }^{4,5} \beta$-diketone are a versatile precursor for the synthesis of various heterocycles such as Pyrazole,${ }^{6}$ Isoxazole, ${ }^{7}$ triazoles, ${ }^{8}$ flavones, ${ }^{9}$ benzodiazepine ${ }^{10}$ and Pyrimidine $^{11}$. $\beta$-diketones are important pharmacophores of HIV-1 integrase (1N)inhibitor. ${ }^{12} \beta$-diketones are 1,3-diketones, $\beta$-diketones with different substituents and their complexes have been synthesized and their properties such as Lewis acidity, standard molar enthalpies of formation, standard molar enthalpies of sublimation, vapor pressure and volatility have been studied. ${ }^{13} \beta$-diketones used in extraction processes of many metal ions. ${ }^{14}$ As metal(II) complexes have chelating ability hence gained considerable

Rasayan J. Chem., 12(1), 101-113(2019)

http://dx.doi.org/10.31788/RJC.2019.1214045

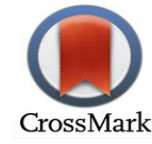


RASĀYAN J. Chem.

Vol. 12 | No. 1 |101 - 113| January - March | 2019

interest in nucleic acid chemistry. The coordination behavior of $\beta$-diketones also has significant influences the relative stabilities of the mixed-ligand complexes as well as their use in biomedicine. ${ }^{15,16}$ Moreover, newly synthesized ligand and transition metal chelates demonstrated effective antibacterial, antioxidant activities. Furthermore, it is also reviewed that no attention has been directed to design and synthesize molecules bearing $\beta$-diketone and its transition metal complexes, moieties in one molecular frame. Rationally it is expected that $\beta$-diketones on chelation in one molecular frame work then will display enhanced anti-inflammatory activity because of synergy. Therefore, here we have developed some new $\beta$-diketone derived transition metal complexes bearing with hope to get the molecules with enhanced anti-inflammatory activity.

\section{EXPERIMENTAL}

All the chemicals were obtained from commercial sources and used as received. The required compounds were synthesized by standard procedures. The solvent and reagents used for the synthetic work are of analytical grade. Melting points were determined in open glass capillaries and were uncorrected. ${ }^{1} \mathrm{H}$ NMR and ${ }^{13} \mathrm{C}$ NMR were recorded on a varian NMR mercury 300 using tetramethylsilane as an internal standard and $\mathrm{CDCl}_{3}$ as a solvent. The Infrared Spectra $\left(4000-400 \mathrm{~cm}^{-1}\right)$ were recorded on Shimadzu. Carbon, Hydrogen and Oxygen elemental analyses were carried out on EuroVector EA 3000 Elemental Analyser.

\section{Synthesis of 3-Hydroxy-3-(2-hydroxyphenyl)-1-(2-iodo-5-methyl phenyl)prop-2-en-1-one (L)}

The preparation of the ligand (L) and its transition metal complexes used in this work is shown in Fig.- 1 . First 2-Acetylphenyl 2-iodo-5-methyl benzoate was obtained from 2-iodo-5-methyl benzoic acid, 2hydroxyacetophenone and $\mathrm{POCl}_{3}$ by the reported method. ${ }^{17}$ In the next step 2-acetylphenyl 2-iodo-5methyl benzoate and pulverized $\mathrm{KOH}$ were dissolved in $20.0 \mathrm{~mL}$ of pyridine. The reaction mixture was magnetically stirred at room temperature for $3 \mathrm{hrs}$ and the progress of the reaction was monitored by TLC. After the completion of the reaction, the reaction mixture was poured on crushed ice and acidified with $1 \mathrm{M} \mathrm{HCl}$. The obtained solid yellow product was filtered and recrystallized from ethanol to get chromatographically (TLC) pure product. Yield: $72 \%, \mathrm{mp}: 119^{\circ} \mathrm{C}$.

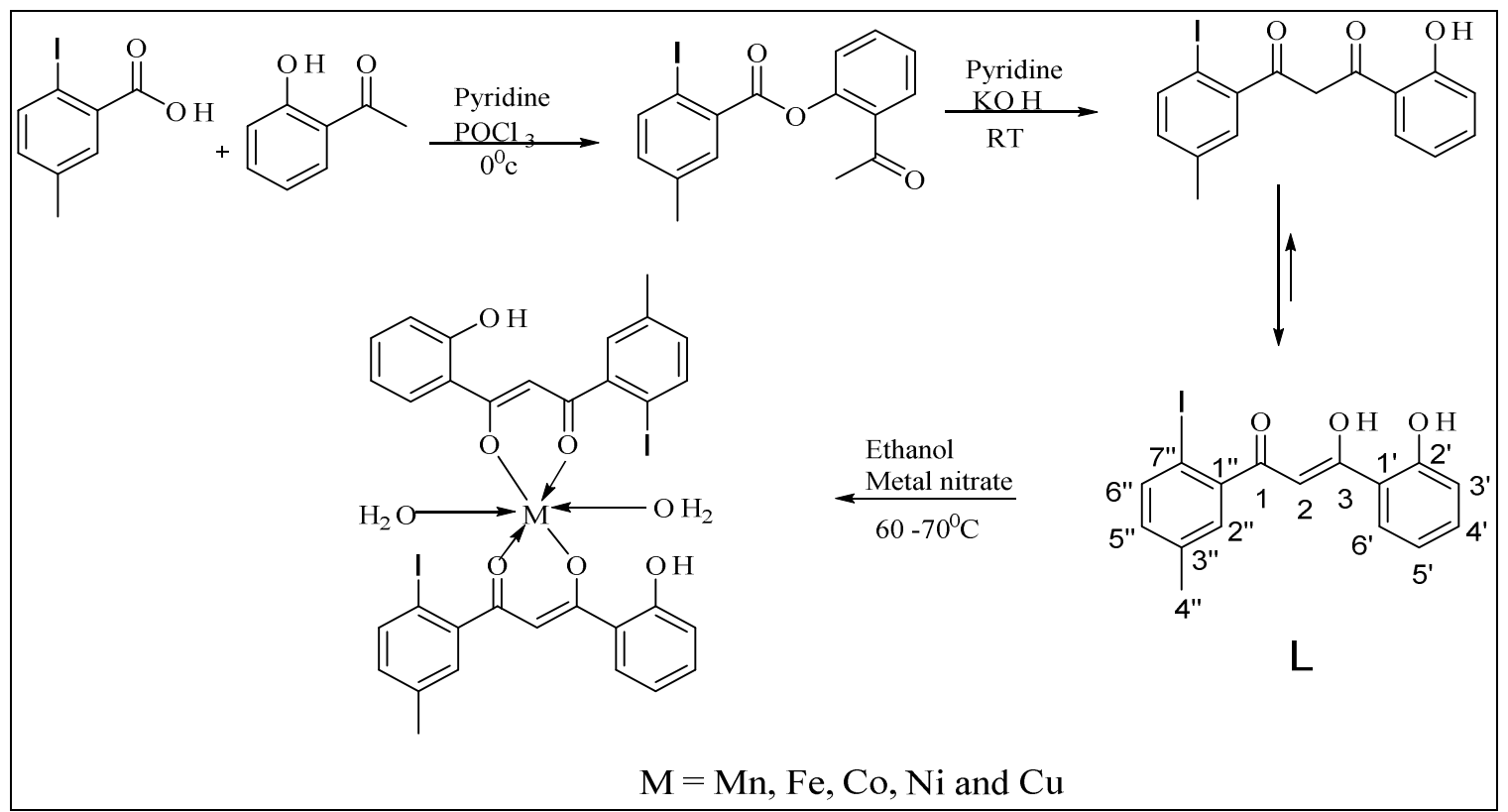

Fig.- 1: Scheme for the Synthesis of Ligand (L) and its Metal Complexes

\section{Synthesis of Metal Complexes}

The metal complexes were prepared by the addition of hot solution of the appropriate metal nitrate in ethanol $(25 \mathrm{ml})$ to the hot solution of the ligand in the same solvent $(25 \mathrm{ml})$. The resulting mixture was 
stirred under reflux for one hour whereupon the complex precipitated. They were collected by filtration, washed thoroughly with ethanol and dried in vacuum.

\section{RESULTS AND DISCUSSION}

The prepared metal complexes were powdered, shows colored, stable under the atmospheric condition and soluble in polar solvents like DMSO and DMF. The elemental analytical data for the complex was presented in Table-1, which was in good agreement with 1:2 (metal : ligand) stoichiometry for all the prepared metal complexes, Magnetic study reveals that the complexes of $\mathrm{Mn}, \mathrm{Fe}, \mathrm{Co}, \mathrm{Ni}$, and $\mathrm{Cu}$ were paramagnetic in nature. The molar conductance of the metal complexes of the $10^{-3} \mathrm{M}$ solution in DMF was found in the range of 6.4 to $7.4 \mathrm{~cm}^{-1} \mathrm{~mol}^{-1}$, which indicates that these complexes were nonelectrolytic in nature.

Table -1: Analytical, Physical and Molar Conductance Data of the Synthesized Compounds

\begin{tabular}{|c|c|c|c|c|c|c|c|}
\hline \multirow[t]{2}{*}{ Compounds } & \multirow[t]{2}{*}{ F. W } & \multirow{2}{*}{$\begin{array}{l}\text { MP } \\
\left({ }^{\circ} \mathrm{C}\right)\end{array}$} & \multirow{2}{*}{$\begin{array}{c}\text { Molar } \\
\text { Conductance }\end{array}$} & \multicolumn{4}{|c|}{ Elemental Analysis \% } \\
\hline & & & & $\mathrm{C}$ & $\mathrm{H}$ & $\mathrm{O}$ & $\mathrm{M}$ \\
\hline $\mathrm{L}$ & 380.18 & $110^{\circ}$ & 7.09 & $\begin{array}{l}50.381 \\
(50.55)\end{array}$ & $\begin{array}{c}3.09 \\
(3.45)\end{array}$ & $\begin{array}{c}12.16 \\
(12.63)\end{array}$ & $-\overline{---}$ \\
\hline$\left[\mathrm{Mn}(\mathrm{L})_{2}\right](\mathrm{H} 2 \mathrm{O})_{2}$ & 849.31 & $>300^{\circ}$ & 7.4 & $\begin{array}{l}43.887 \\
(44.02)\end{array}$ & $\begin{array}{l}3.636 \\
(3.15)\end{array}$ & $\begin{array}{l}16.204 \\
(16.66)\end{array}$ & $\begin{array}{c}6.21 \\
(6.36)\end{array}$ \\
\hline$\left[\mathrm{Fe}(\mathrm{L})_{2}\right]\left(\mathrm{H}_{2} \mathrm{O}\right)_{2}$ & 850.22 & $>300^{\circ}$ & 7.2 & $\begin{array}{c}44.102 \\
(44.420)\end{array}$ & $\begin{array}{l}3.057 \\
(3.15)\end{array}$ & $\begin{array}{l}16.168 \\
(16.64)\end{array}$ & $\begin{array}{l}6.056 \\
(6.45)\end{array}$ \\
\hline$\left[\mathrm{Co}(\mathrm{L})_{2}\right]\left(\mathrm{H}_{2} \mathrm{O}\right)_{2}$ & 853.31 & $>300^{\circ}$ & 6.6 & $\begin{array}{l}44.476 \\
(45.26) \\
\end{array}$ & $\begin{array}{l}3.025 \\
(3.31) \\
\end{array}$ & $\begin{array}{l}16.049 \\
(16.58) \\
\end{array}$ & $\begin{array}{l}6.268 \\
(6.91) \\
\end{array}$ \\
\hline$\left[\mathrm{Ni}(\mathrm{L})_{2}\right]\left(\mathrm{H}_{2} \mathrm{O}\right)_{2}$ & 853.07 & $>300^{\circ}$ & 6.4 & $\begin{array}{l}44.150 \\
(44.28)\end{array}$ & $\begin{array}{l}3.364 \\
(3.14)\end{array}$ & $\begin{array}{l}16.739 \\
(16.59)\end{array}$ & $\begin{array}{l}6.257 \\
(6.76)\end{array}$ \\
\hline$\left[\mathrm{Cu}(\mathrm{L})_{2}\right]\left(\mathrm{H}_{2} \mathrm{O}\right)_{2}$ & 857.92 & $>300^{\circ}$ & 7.3 & $\begin{array}{l}44.287 \\
(44.80)\end{array}$ & $\begin{array}{l}3.071 \\
(3.29)\end{array}$ & $\begin{array}{l}16.392 \\
(16.50)\end{array}$ & $\begin{array}{l}6.995 \\
(7.28)\end{array}$ \\
\hline
\end{tabular}

UV-Vis Electronic Absorption Spectra of Metal $\beta$-Diketone Complexes

The formation of the metal $\beta$-diketone complexes was also confirmed by UV-visspectra. The spectra of the organic ligand and its metal complexes (1-5) in DMSO solutions $\left(10^{-3} \mathrm{M}\right)$ at room temperature were shown in Fig.-1 and 2 and important data are summarized in Table-2. The ligand has three strong absorptions as seen from Fig.-1. The band of the shortest wavelength appearing at $265 \mathrm{~nm}$ may be attributed to $\pi \rightarrow \pi^{*}$ transition of the aromatic ring moiety. The second band observed at $317 \mathrm{~nm}$ is attributed to $n \rightarrow \pi *$ electronic transition of keto carbonyl and the enol carbonyl group of the tautomer. The third band appearing around $361 \mathrm{~nm}$ can be assigned to $\pi \rightarrow \pi^{*}$ transition involving the whole conjugation and delocalization electronic system of the ligand. ${ }^{18,}{ }^{19}$ In the spectra of metal $\beta$-diketone complexes, the band of the longest wavelength shows an obvious bathochromic shift relative to their free ligand, while the other two absorption peaks at 265 and $317 \mathrm{~nm}$ in the free ligand disappears or is observed as a shoulder with different intensity. The absorption shift and intensity change in the spectrum of the ligand and complexes originate from the metalation which can readily convert diketo form into enol form, increase the conjugation and delocalization of the whole electronic system and result in the energy change of the $\pi \rightarrow \pi^{*}$ transition of the conjugated chromophore. ${ }^{20}$ The results clearly indicate that the ligand coordinates to metal ions, which are in accordance with the results of IR spectra. Furthermore, there are no observable transitions in the visible region indicating the absence of any ligand to metal charge transfer (LMCT) transitions. These bands can come from the forbidden $\mathrm{d}-\mathrm{d}$ transition, which is generally too weak to be detected. They may be lost in the low-energy tail of the charge transfer transition. ${ }^{21,22}$ The results in our experiments can be explained as follows: after metal ion was connected with the oxygen atom of enol hydroxyl, the oxygen atom became easier to give an unbonded electron to $\pi$-electron system, which made a bathochromic shift of absorption of ligand.

${ }^{1} \mathrm{H},{ }^{13} \mathrm{C}-\mathrm{NMR}$ and Mass Spectral Data of the Ligand (L)

${ }^{1}$ H-NMR $\left(400 \mathrm{MHz}, \mathrm{CDCl}_{3}\right) \delta: 2.36(\mathrm{~s}, 3 \mathrm{H}) 6.57$ (s, 1H, vinylic), $6.95-7.85(\mathrm{~m}, 7 \mathrm{H}, \mathrm{Ar}-\mathrm{H}), 12.03(\mathrm{~s}, 1 \mathrm{H}$ Ar-OH), 15.13 (s, $1 \mathrm{H}$ enolic-OH). 

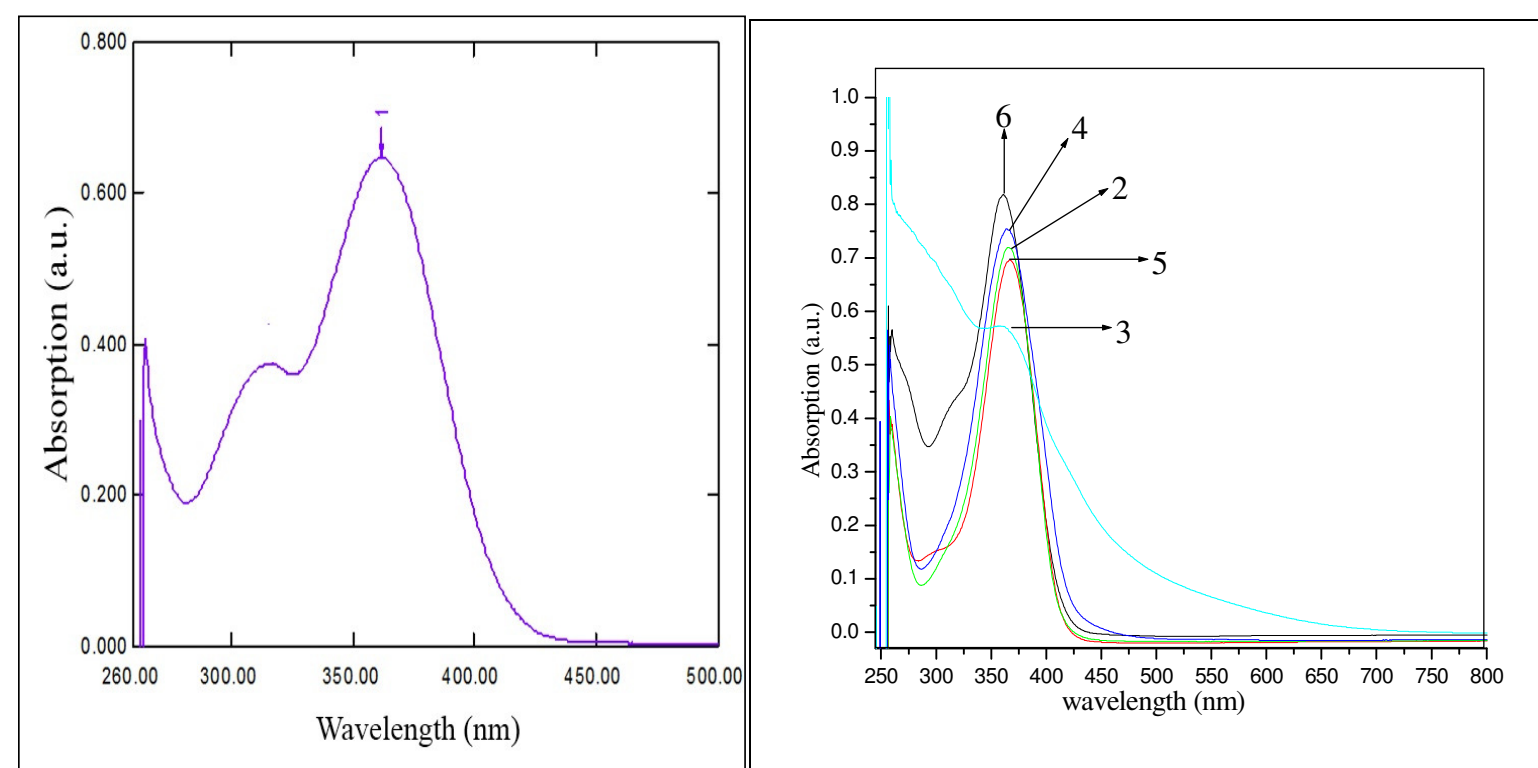

Fig.- 2: Absorption Spectra for the Ligand (1) and Absorption Spectra for the Complexes 2 $=\left[\mathrm{Mn}(\mathrm{L})_{2}\right]\left(\mathrm{H}_{2} \mathrm{O}\right)_{2}$, $3=\left[\mathrm{Fe}(\mathrm{L})_{2}\right]\left(\mathrm{H}_{2} \mathrm{O}\right)_{2}, 4=\left[\mathrm{Co}(\mathrm{L})_{2}\right]\left(\mathrm{H}_{2} \mathrm{O}\right)_{2}, 5=\left[\mathrm{Ni}(\mathrm{L})_{2}\right]\left(\mathrm{H}_{2} \mathrm{O}\right)_{2} \& 6=\left[\mathrm{Cu}(\mathrm{L})_{2}\right]\left(\mathrm{H}_{2} \mathrm{O}\right)_{2}$.

Table-2: Electronic Spectral Data of the Synthesized Compounds

\begin{tabular}{c|c|c}
\hline S. No. & Compounds & Absorption/Wavelength \\
\hline 1 & $\mathrm{~L}$ & $0.648 / 360$ \\
\hline 2 & {$\left[\mathrm{Mn}(\mathrm{L})_{2}\right](\mathrm{H} 2 \mathrm{O})_{2}$} & $0.714 / 369$ \\
\hline 3 & {$\left[\mathrm{Fe}(\mathrm{L})_{2}\right]\left(\mathrm{H}_{2} \mathrm{O}\right)_{2}$} & $0.564 / 367$ \\
\hline 4 & {$\left[\mathrm{Co}(\mathrm{L})_{2}\right]\left(\mathrm{H}_{2} \mathrm{O}\right)_{2}$} & $0.744 / 369$ \\
\hline 5 & {$\left[\mathrm{Ni}(\mathrm{L})_{2}\right]\left(\mathrm{H}_{2} \mathrm{O}\right)_{2}$} & $0.714 / 366$ \\
\hline 6 & {$\left[\mathrm{Cu}(\mathrm{L})_{2}\right]\left(\mathrm{H}_{2} \mathrm{O}\right)_{2}$} & $0.807 / 363$ \\
\hline
\end{tabular}

${ }^{13} \mathrm{C}-\mathrm{NMR}\left(400 \mathrm{MHz}, \mathrm{CDCl}_{3}\right)$ 8:195.90 (s C-1, C=O), 97.83 (C-2, -CH=), 179.80 (s, C-3), 118.55 (s, C-1'), 162.70 (s, C-2'), 118.83 (s, C-3'), 130.49 (s, C-4'), 119.28 (s, C-5'), 128.90 (s, C-6'), 140.47 (s, C-1' '), 132.85 (s, C-2”'), 138.52 (s, C-3”), 20.90 (s, C-4”), 137.00 (s, C-5”), 139.00 (s, C-6”), 90.06 (s, C-7'”)

LC-MS (ESI') at m/z 379.9

\section{IR Spectra}

The important infrared spectral bands and their tentative assignments for the ligand and its complexes are given shown in Fig.-3. The free ligand as expected shows intramolecular hydrogen bonded keto-enol tautomerism, exhibits a series of vibration bands at $1678,1608,1579$ and $1188 \mathrm{~cm}^{-1}$ which are due to keto carbonyl $v(\mathrm{C}=\mathrm{O})$, enol carbonyl $v(\mathrm{C}=\mathrm{O})$, enol form $v(\mathrm{C}=\mathrm{C})$ and $v(\mathrm{C}-\mathrm{O})$ respectively. Upon coordination, the peak at $1678 \mathrm{~cm}^{-1}$ attributed to $v(\mathrm{C}=\mathrm{O})$ vibration originating from ketoic form has disappeared, indicating that the $\beta$-diketone ligand act as an enol form tautomer in the complexes. The shifting of the characteristic bands for the free ligand to lower frequency in all the metal $\beta$-diketone complexes, denotes the coordination of carbonyl group to the central metal ion. In addition to this, the characteristic band for free ligand shifts to a lower frequency in metal complexes of $\beta$-diketone as shown in Fig.-3. This lower shifting is due to the loss of an acidic proton from enol hydroxyl moieties and bonding of both enol hydroxyl oxygen and enol carbonyl oxygen to the metal ion in a chelate mode. So the enhanced conjugation from keto-enol tautomer to enol form hexahydric chelate ring gives a natural interpretation of the lower frequency shifts seen experimentally in the complexes. 
RASĀYAN J. Chem.

Vol. 12 | No. 1 |101 - 113| January - March | 2019

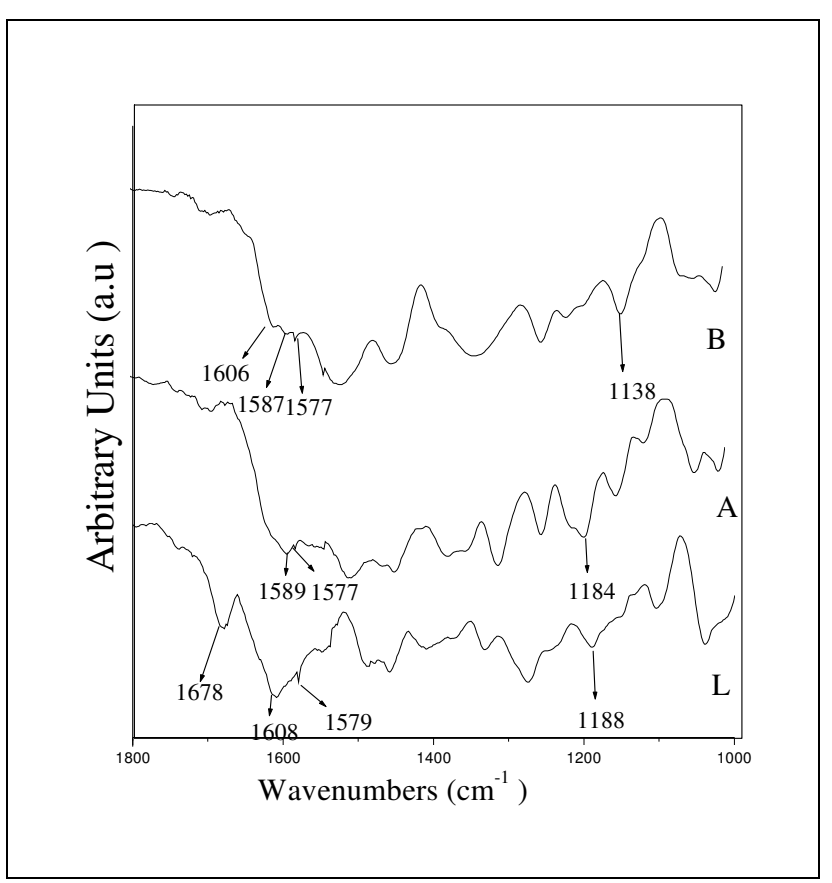

(a)

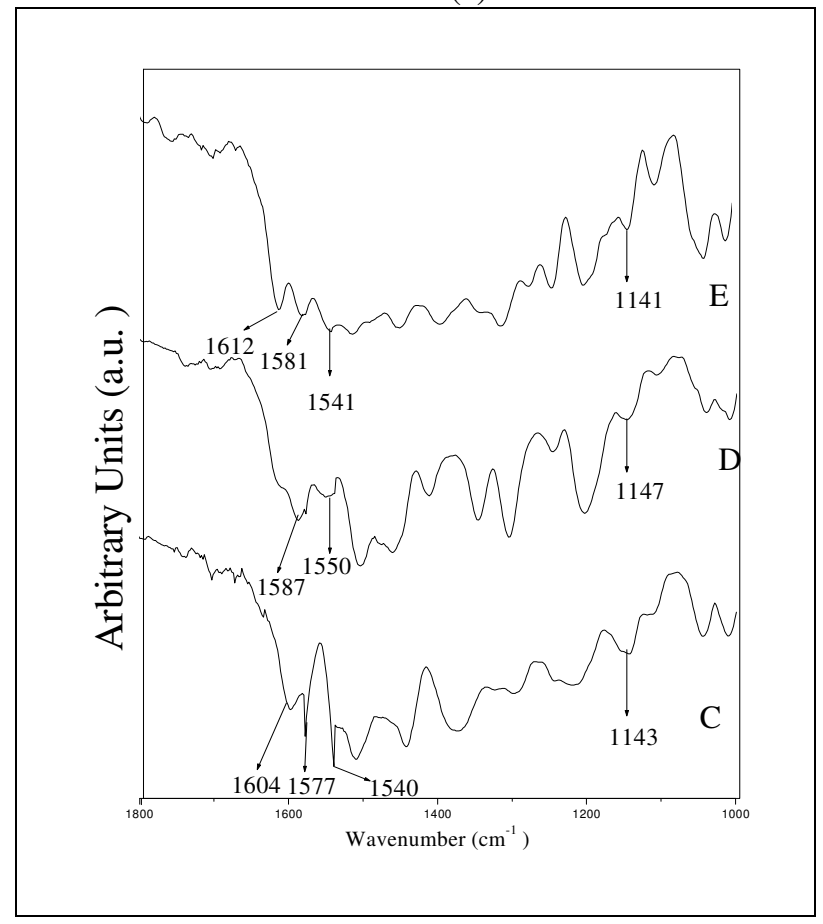

(c)

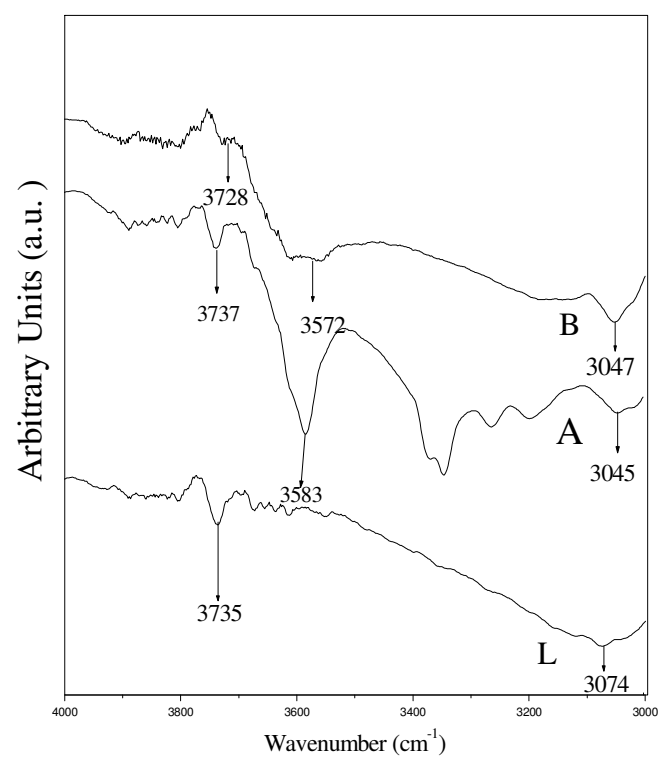

(b)

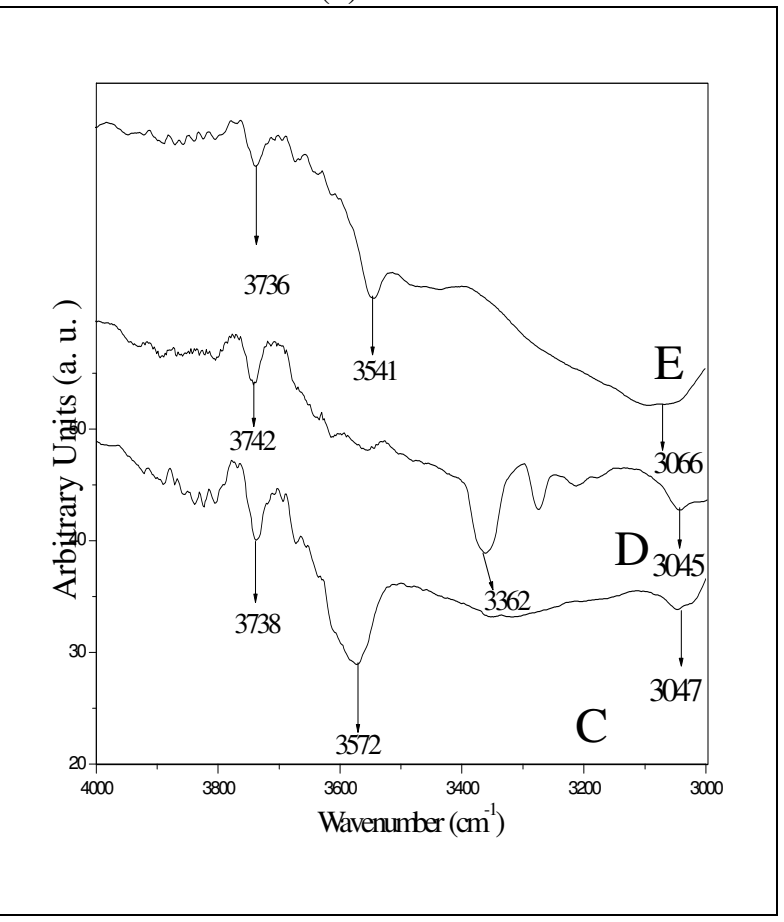

(d)

Fig.-3: FT-IR Spectra of Ligand (L) and its Metal Complexes: Fig.(a) and (c) $1000-1800 \mathrm{~cm}^{-1}$; Fig. (b) and (d) 3000-4000 $\mathrm{cm}^{-1} . \mathrm{L}=$ ligand, $\mathrm{A}=\left[\mathrm{Mn}(\mathrm{L})_{2}\right]\left(\mathrm{H}_{2} \mathrm{O}\right)_{2}, \mathrm{~B}=\left[\mathrm{Fe}(\mathrm{L})_{2}\right]\left(\mathrm{H}_{2} \mathrm{O}\right)_{2}, \mathrm{C}=\left[\mathrm{Co}(\mathrm{L})_{2}\right]\left(\mathrm{H}_{2} \mathrm{O}\right)_{2}$, $\mathrm{D}=\left[\mathrm{Ni}(\mathrm{L})_{2}\right]\left(\mathrm{H}_{2} \mathrm{O}\right)_{2} \& \mathrm{E}=\left[\mathrm{Cu}(\mathrm{L})_{2}\right]\left(\mathrm{H}_{2} \mathrm{O}\right)_{2}$.

In the IR spectra there is a weak and broad absorption at $3074 \mathrm{~cm}^{-1}$ in the free ligand which would be due to the unsaturated $v \mathrm{CH}$ stretching vibration of the aromatic ring, for metal $\beta$-diketone complexes, this band decreased in intensity and most likely originating from the metalation which increases the conjugation and delocalization of the aromatic ring with a neighboring enol form hexahydric ring. The 
appearance of a broad band centered at $3362-3583 \mathrm{~cm}^{-1}$ due to $v(\mathrm{OH})$ in all the complexes may be due to the presence of coordinated water in them.which is not obviously seen with the free ligand. This appearance of absorption bands is assigned to $v \mathrm{OH}$ and $\rho \mathrm{rOH}$ vibrations. ${ }^{23,}{ }^{24}$ Therefore, the FT-IR spectra indicate that the metal complexes may prefer may form a hexacoordinated form. These results agree well with that of elemental analytical data above Table- 1 and TG analyses below. The appearance of peaks above $3700 \mathrm{~cm}^{-1}$ in ligand and metal complexes is due to atmospheric moisture (gaseous) molecules. ${ }^{25}$ The IR spectra of the metal complexes of $\beta$-diketone are very similar, except some of the slight shift and intensity change of a vibration band caused by different metal ions.

\section{Thermal Analysis}

Thermogravimetry analysis was conducted for a powdered sample of complexes $\mathrm{Cu}, \mathrm{Ni}$, and $\mathrm{Mn}$. The measurement was performed in the temperature range of $25-1000^{\circ} \mathrm{C}$ with a heating rate of $10^{\circ} \mathrm{C} / \mathrm{min}$ in an air atmosphere. The DTA measurements were performed for the same complexes.

The thermogram of the complex A showed a mass loss $4.772 \%$ (calculated 4.243) in the temperature range $35-177^{\circ} \mathrm{C}$ and a sharp endotherm at $141.35^{\circ} \mathrm{C}$ which clearly indicates removal of two coordinated water molecules. The complex first show slow decomposition from 185 to $575^{\circ} \mathrm{C}$, with $68.06 \%$ (calculated $69.32 \%$ ) mass loss, a sharp exotherm with $441.99^{\circ} \mathrm{C}$ in the DTA may be attributed the loss of partially decomposed ligand part from the complex. The second step of the decomposition from 600 to $725^{\circ} \mathrm{C}$ with a mass loss of $17.76 \%$ (calculated $18.08 \%$ ) corresponds to the decomposition of remaining part of the ligand. A broad exothermic peak at $605.43^{\circ} \mathrm{C}$ in the DTA region was observed for this step. After $760^{\circ} \mathrm{C}$ a horizontal curve has been observed which corresponds to a mixture of metal oxide as an ultimate pyrolysis product i.e the mass of the final residue $\mathrm{MnO}, 9.41 \%$ (calculated $8.35 \%$ ) which is in agreement.

The thermogram of the complex $\mathbf{D}$ showed a mass loss of $5.136 \%$ (calculated $4.22 \%$ ) in the temperature range $35-219^{\circ} \mathrm{C}$. and a sharp endotherm at $196.84^{\circ} \mathrm{C}$ which clearly indicate removal of two coordinated water molecules. The complex first show slow decomposition from 225 to $585^{\circ} \mathrm{C}$, with $64.54 \%$ (calculated $65 \%$ ) mass loss, a sharp exotherm with $544.89^{\circ} \mathrm{C}$ in the DTA may correspond to the removal of partially decomposed ligand part from the complex. The second step of the decomposition from 605 to $753^{\circ} \mathrm{C}$ with a mass loss of $21 \%$ (calculated $22.47 \%$ ) suggests the elimination of the remaining part of the ligand. A broad exothermic peak at $566.08^{\circ} \mathrm{C}$ in the DTA region was observed for this step. The mass of the final residue $\mathrm{NiO}, 8.25 \%$ which is in agreement with respect to calculated $6.59 \%$.

The thermogram of the complex $\mathbf{E}$ showed a mass loss of $4.899 \%$ (calculated $4.22 \%$ ) in the temperature range $35-193.81{ }^{\circ} \mathrm{C}$. and a sharp endotherm at $105^{\circ} \mathrm{C}$ which clearly indicate removal of two coordinated water molecules. The complex first show slow decomposition from 205 to $615^{\circ} \mathrm{C}$, with $66 \%$ (calculated $67.36 \%$ ) mass loss, a sharp exotherm with $291.67^{\circ} \mathrm{C}$ in the DTA may be attributed to the loss of partially decomposed ligand part from the complex. The second step of the decomposition from 620 to $795^{\circ} \mathrm{C}$ with a mass loss of $17.55 \%$ (calculated $18.92 \%$ ) indicates the elimination of the remaining thermally degradable part of the complex. A broad exothermic peak at $566.08^{\circ} \mathrm{C}$ in the DTA region was observed for this step. Above $700{ }^{\circ} \mathrm{C}$, a constant weight region has been observed due to metal oxide, as a final pyrolysis product. The mass of the final residue $\mathrm{CuO}, 11.78 \%$ which is in agreement with calculated $10.45 \%$.

In all steps, decomposition of the ligand, occurred and residues of metal oxide are left. This is confirmed with endothermic and exothermic peaks through all stages of decomposition.

\section{Antibacterial Screening}

The antimicrobial screening of the synthesized compounds (ligand and its metal complexes) have been tested in vitro, as growth inhibiting agents. The antibacterial screening was carried out using by Agar diffusion method against some strains of bacteria such as $S$. aureus, S. typhi, E. coli respectively. The compounds were dissolved in DMSO and two different concentrations were used for screening process i.e., 250 and $500 \mathrm{ppm}$. Wells were made on petriplates containing solidified 20ml Muller Hinton agar medium (HiMedia, Mumbai). 
RASĀYAN J. Chem.

Vol. 12 | No. 1 |101 - 113| January - March | 2019
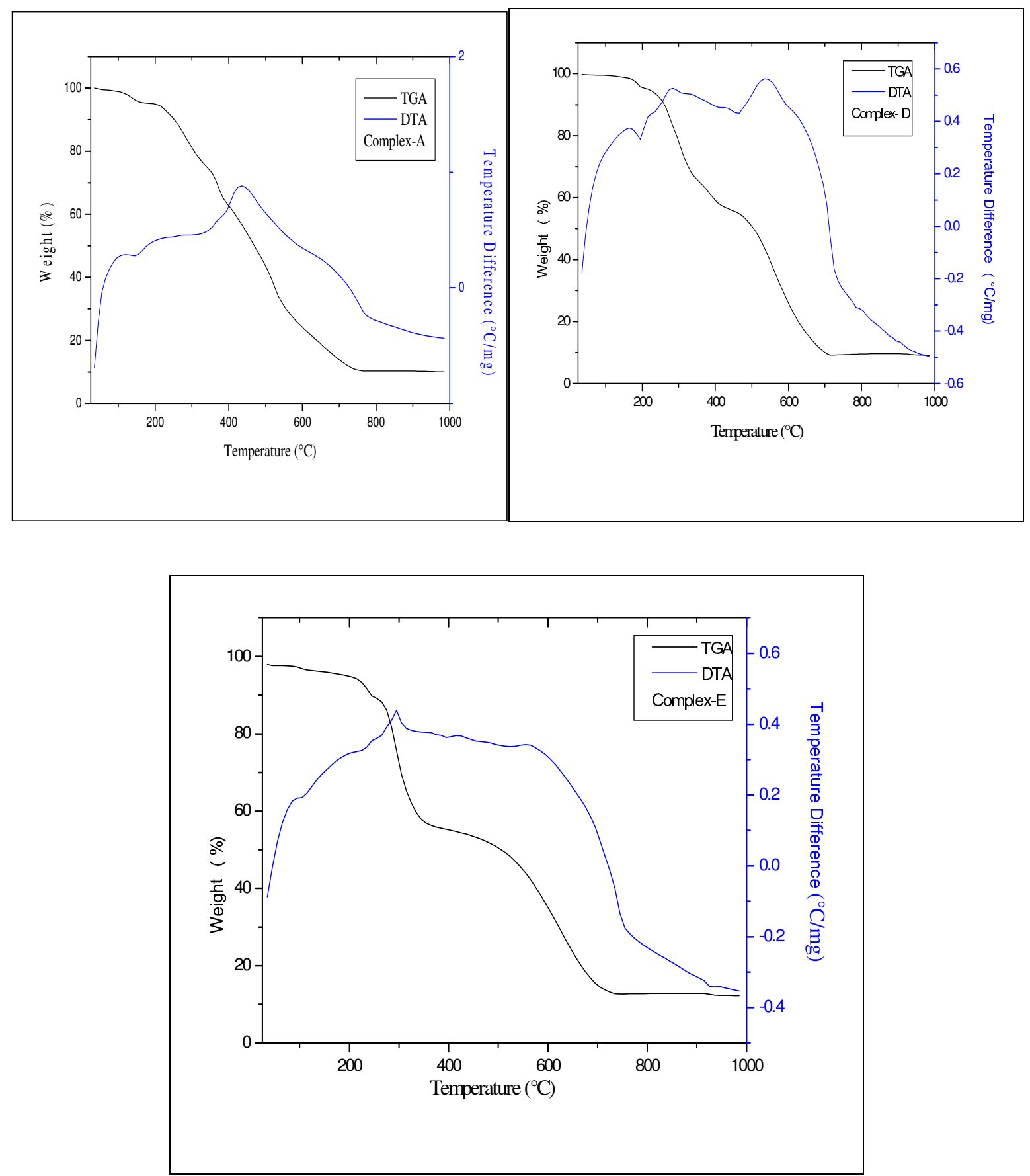

Fig.- 4: TGA-DTA Curves of $\mathrm{A}=\left[\mathrm{Mn}(\mathrm{L})_{2}\right]\left(\mathrm{H}_{2} \mathrm{O}\right)_{2}, \mathrm{D}=\left[\mathrm{Ni}(\mathrm{L})_{2}\right]\left(\mathrm{H}_{2} \mathrm{O}\right)_{2} \& \mathrm{E}=\left[\mathrm{Cu}(\mathrm{L})_{2}\right]\left(\mathrm{H}_{2} \mathrm{O}\right)_{2}$.

These plates were inoculated with 20-24 hour culture of bacterial strains. Control plates with Gentamycin and solvent were maintained. The antibacterial activity was assayed by measuring the diameter of the inhibition zone formed around the well. The results of the antibacterial activity of synthesized compounds have shown that the metal complexes exhibit greater antimicrobial activity than that of the free ligand. The examination of antibacterial screening data revealed that some of the tested compounds showed moderate to good bacterial inhibition. Fe(III), the complex was found to be inactive against $S$. aureus. $\mathrm{Mn}(\mathrm{II}), \mathrm{Fe}(\mathrm{III}), \mathrm{Ni}$ (II) complex was found to be inactive against $S$. typhimurium. While $\mathrm{Mn}$ (II), $\mathrm{Fe}(\mathrm{III})$, $\mathrm{Co}$ (II) and $\mathrm{Ni}$ (II) complexes showed no activity towards E. coli. Whereas the $\mathrm{Cu}$ (II) complex showed 
good activity against $S$. aureus and Co(II) complex showed good activity against $S$. typhi. However, in the case of E. coli only $\mathrm{Cu}$ (II) complex exhibits activity and rest of the compounds were found to be inactive. Among the synthesized metal complexes, the increased antibacterial activity of some of the metal complexes compared with that of ligand, is due to chelating tends to make metal complexes act as more influential and powerful bacteriostatic agents, thus inhibiting the growth of the microorganisms. The Overtone's concept and chelation theory explains the increased antimicrobial effect as the chelation tend to make the ligand a more powerful and potent bacterial agent. ${ }^{26}$ On chelation, the polarity of the metal ion will be reduced to a better range due to the overlap of the ligand orbital and partial sharing of the positive charge of the metal ion with donor groups. Further, it increases the delocalization of p-electrons over the whole chelate ring and enhances the penetration of the complexes into lipid membranes and blocking of the metal binding sites in the enzymes of microorganisms. These complexes may also disturb the respiration process of the cell and thus block the synthesis of proteins, which restricts further growth of the organism. ${ }^{27,} 28$ In general metal complexes are more active than the ligands because metal complexes may serve as a vehicle for activation of ligands as the principle cytotoxic species.

\section{Anti-inflammatory Activity}

The anti-inflammatory activities of the synthesized compounds are assessed by in vitro HRBC membrane stabilization method. Blood is collected from healthy volunteers. The collected blood was mixed with equal volume of Alsever's solution (Dextrose 2\%, Sodium citrate $0.8 \%$, Citric acid $0.05 \%$, Sodium chloride $0.42 \%$ and Distilled water $100 \mathrm{ml}$ ) and centrifuged with Isosaline. To $1 \mathrm{ml}$ of HRBC suspension equal volume of the test drug in different concentrations are added. All the assay mixtures are incubated at $37^{\circ} \mathrm{C}$ for 30 minutes and centrifuged. The hemoglobin content in the supernatant solution is estimated by using spectrophotometer at $560 \mathrm{~nm}$. The percentage of heamolysis was calculated by using the following formula: $:^{29,} 30$

$\%$ Haemolysis $=($ Optical density of Test sample / Optical density of Control $) \times 100$

In this case, the standard used was Diclofenac sodium (DFS) which acts by stabilizing the membrane. The hyposaline used causes the heamolysis of RBC, as the concentration of hypo saline increases this causes the membrane components to leak out. This is then measured spectrophotometrically at $560 \mathrm{~nm}$. Thus increases the concentration of hypo saline, increases the O.D (as increase concentration of hypo saline increases the extent of heamolysis).

DFS stabilizes the membrane, thereby reducing the heamolysis. Thus with the increase in the components are prevented from leaking, Thus as the concentration of DFS increases, the O.D decreases thereby decreasing the effect of the hypo tonicity caused by hypo saline. ${ }^{31}$

The lysosomol enzymes produced during the process of inflammation produces a variety of disorders. The extra cellular activity of these enzymes is said to be related to the acute of chronic inflammation. The non-steroidal drug (DFS in case) act either by inhibiting these lysomol enzymes or by stabilizing the lysosomal membrane. Since HRBC is similar to the lysosomal membrane and hence the study was undertaken to check the stability of HRBC membrane by these synthesized ligand and metal complexes to predict the anti-inflammatory activity.

The ability of the test compound to stabilize the membrane or to prevent haemolysis is compared with the standard and tabulated in Table-4. Metal complexes enhance inhibition activity of lysomol enzymes or stabilize the lysosomalmembranethan the free ligand. ${ }^{32}$

\section{Antioxidant Activity}

DPPH is a stable free radical at room temperature and accepts an electron or hydrogen radical to become a stable diamagnetic molecule. The reduction capability of the DPPH radical is determined by the decrease in its absorbance at $517 \mathrm{~nm}$, induced by antioxidants. The percentage reduction in absorbance was calculated from the initial and final absorbance of each solution. Percentage scavenging of DPPH radical was calculated using the formula:

$$
\% \text { Scavenging of DPPH }=[(\text { control-Test }) / \text { control }] \times 100
$$


RASĀYAN J. Chem.

Vol. 12 | No. 1 |101 - 113| January - March | 2019

We conducted a systematic investigation to study the antioxidant potency of the compounds by DPPH method using L-ascorbic acid as a reference. The experiment was performed in triplicate. $0.1 \mathrm{Mm}$ solution of DPPH in methanol was prepared and $1.0 \mathrm{ml}$ of this solution was added to $3.0 \mathrm{ml}$ of the sample solution in DMSO at different concentrations $(100-400 \mu \mathrm{g} / \mathrm{ml})$. All reaction mixtures were kept in the dark for $30 \mathrm{~min}$ and the optical density was noted at $517 \mathrm{~nm}$. The results of the radical scavenging effect of the compounds at different concentrations $(100-400 \mu \mathrm{g} / \mathrm{ml})$ are shown in table 5. It is evident from the results that free ligand, L showed remarkably less potent activity than metal complexes (1-5) which is mainly due to the chelation of organic ligand with the metal ion. ${ }^{33}$

Table-3: Antibacterial Screening of the Synthesized Compounds.

\begin{tabular}{c|c|c|c|c|c|c}
\hline \multirow{2}{*}{ Compounds } & \multicolumn{2}{|c}{ S. aureus } & \multicolumn{2}{c}{ S.typhimurium } & \multicolumn{2}{c}{ E.coli } \\
\cline { 2 - 7 } & $250 p m m$ & $500 p p$ & $250 p p m$ & $500 p p m$ & $250 p p m$ & $500 p p m$ \\
\hline $\mathrm{L}$ & 8 & 10 & 10 & 11 & 7 & 7 \\
\hline$\left[\mathrm{Mn}(\mathrm{L})_{2}\right]\left(\mathrm{H}_{2} \mathrm{O}\right)_{2}$ & 11 & 13 & ---- & ---- & ---- & ---- \\
\hline$\left[\mathrm{Fe}(\mathrm{L})_{2}\right]\left(\mathrm{H}_{2} \mathrm{O}\right)_{2}$ & ---- & ---- & ---- & ---- & ---- & ---- \\
\hline$\left[\mathrm{Co}(\mathrm{L})_{2}\right]\left(\mathrm{H}_{2} \mathrm{O}\right)_{2}$ & 10 & 11 & 12 & 15 & ---- & --- \\
\hline$\left[\mathrm{Ni}(\mathrm{L})_{2}\right]\left(\mathrm{H}_{2} \mathrm{O}\right)_{2}$ & 11 & 12 & ---- & ---- & --- & 11 \\
\hline$\left[\mathrm{Cu}(\mathrm{L})_{2}\right]\left(\mathrm{H}_{2} \mathrm{O}\right)_{2}$ & 13 & 15 & 12 & 13 & 10 & 11 \\
\hline Gentamycin & 26 & 27 & 26 & 30 & 29 & 31 \\
\hline
\end{tabular}

Table-4: Anti-inflammatory Activity of the Synthesized Compounds

\begin{tabular}{c|c}
\hline Compounds & EC 50( $\mu \mathrm{g} / \mathrm{mL})$ \\
\hline 1 & 2.010 \\
\hline 2 & 2.533 \\
\hline 3 & 0.855 \\
\hline 4 & 17.71 \\
\hline 5 & 15.27 \\
\hline 6 & 13.73 \\
\hline STD & 4.068 \\
\hline
\end{tabular}

The difference in the activity of the $\beta$-diketone metal complexes may be ascribed due to the coordination environment and the redox properties. In general, the redox properties of the complexes depend on several factors such as chelate ring size, axial ligation, the degree of unsaturation in the chelate ring. ${ }^{34}$

\section{Cyclic Voltammetry Measurements (CV)}

Cyclic voltammograms of the ligand $(\mathrm{L})$ and its complexes $4=\left[\mathrm{Ni}(\mathrm{L})_{2}\left(\mathrm{H}_{2} \mathrm{O}\right)_{2}\right]$ and $5=\left[\mathrm{Cu}(\mathrm{L})_{2}\left(\mathrm{H}_{2} \mathrm{O}\right)_{2}\right]$ have been recorded in dimethylformamide (DMF) solution containing $10^{-3} \mathrm{M}$ and $0.1 \mathrm{M}$ sodium perchlorate $\left(\mathrm{NaClO}_{4}\right)$ as supporting electrolyte. An electrode cell was used which was equipped with platinum working and counter electrodes and an $\mathrm{Ag} / \mathrm{AgCl}$ reference electrode in the potential range +2.0 to $-2.0 \mathrm{~V}$. All the solutions were purged with $\mathrm{N}_{2}$ for about 3 minutes prior to each experiment. The electrochemical behavior of the metal complexes is very similar, except some of the slight shift and current caused by different metal ions.

Table-5: Antioxidant Activity of the Synthesized Compounds

\begin{tabular}{c|c|c|c|c}
\hline \multirow{2}{*}{ Compounds } & \multicolumn{4}{|c}{ Concentration } \\
\cline { 2 - 5 } & $100 \mu \mathrm{g} / \mathrm{ml}$ & $200 \mu \mathrm{g} / \mathrm{ml}$ & $300 \mu \mathrm{g} / \mathrm{ml}$ & $400 \mu \mathrm{g} / \mathrm{ml}$ \\
\hline $\mathrm{L}$ & 14.06 & 10.15 & 5.46 & 2.343 \\
\hline$\left[\mathrm{Mn}(\mathrm{L})_{2}\right]\left(\mathrm{H}_{2} \mathrm{O}\right)_{2}$ & 86.71 & 82.81 & 77.34 & 72.65 \\
\hline$\left[\mathrm{Fe}(\mathrm{L})_{2}\right]\left(\mathrm{H}_{2} \mathrm{O}\right)_{2}$ & 32.42 & 27.73 & 22.42 & 8.59 \\
\hline$\left[\mathrm{Co}(\mathrm{L})_{2}\right]\left(\mathrm{H}_{2} \mathrm{O}\right)_{2}$ & 59.29 & 43.67 & 38.51 & 34.14 \\
\hline$\left[\mathrm{Ni}(\mathrm{L})_{2}\right]\left(\mathrm{H}_{2} \mathrm{O}\right)_{2}$ & 81.25 & 74.21 & 68.75 & 63.28 \\
\hline$\left[\mathrm{Cu}(\mathrm{L})_{2}\right]\left(\mathrm{H}_{2} \mathrm{O}\right)_{2}$ & 37.65 & 32.08 & 25.62 & 2.1 \\
\hline $\mathrm{L}-$-ascorbic acid & 14.06 & 10.15 & 5.46 & 2.343 \\
\hline
\end{tabular}


RASĀYAN J. Chem.

Vol. 12 | No. 1 |101 - 113| January - March | 2019

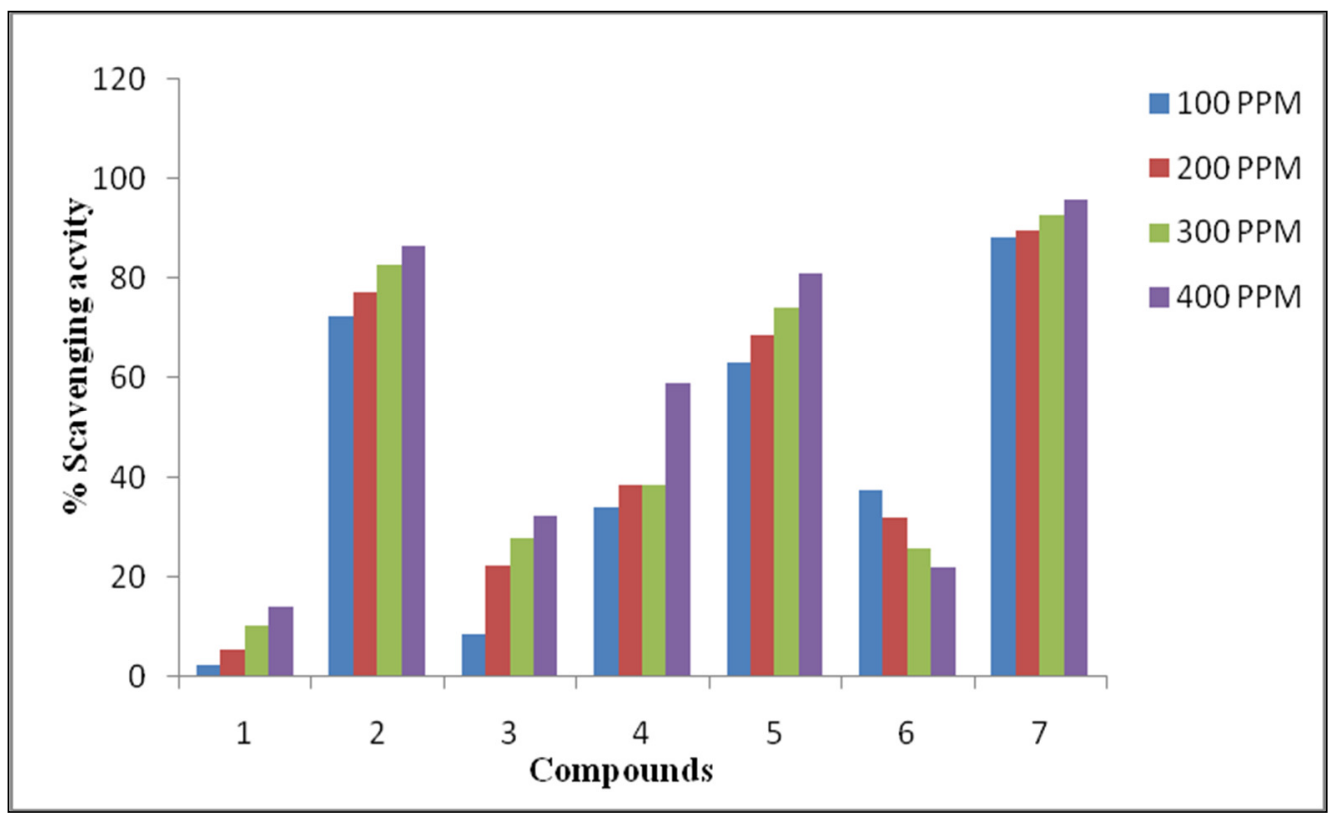

Fig.- 5: Percent Inhibition of DPPH Radical Scavenging Activity, 1= Ligand, $2=\left[\mathrm{Mn}(\mathrm{L})_{2}\right]\left(\mathrm{H}_{2} \mathrm{O}\right)_{2,} 3=$

$\left[\mathrm{Fe}(\mathrm{L})_{2}\right]\left(\mathrm{H}_{2} \mathrm{O}\right)_{2}, 4=\left[\mathrm{Co}(\mathrm{L})_{2}\right]\left(\mathrm{H}_{2} \mathrm{O}\right)_{2}, 5=\left[\mathrm{Ni}(\mathrm{L})_{2}\right]\left(\mathrm{H}_{2} \mathrm{O}\right)_{2} \& 6=\left[\mathrm{Cu}(\mathrm{L})_{2}\right]\left(\mathrm{H}_{2} \mathrm{O}\right)_{2} .7=\mathrm{L}-$ Ascorbic Acid.

The ligand and complexes showed similar electrochemical behavior. The peaks appeared in the forward scan, due to the oxidation, while in the reverse scan, a reduction peak was appeared due to the reduction of the oxidized form. The electrochemical data of all the $\beta$-diketone complexes showed one well-defined redox couple corresponding to $\mathrm{M}(\mathrm{II}) /(\mathrm{I})$. The resulted electrochemical data of the metal complex are given in Table-6. The cyclic voltammogram of the complexes was shown in Fig.-6.

A cyclic voltammogram of the synthesized compound shows one oxidation peak corresponding to the $\mathrm{M}(\mathrm{I}) / \mathrm{M}(\mathrm{II})$ at Epa and reduction peak corresponding to the $\mathrm{M}(\mathrm{II}) / \mathrm{M}(\mathrm{I})$, at Epc respectively tabulated in the table. Further, the quasi-reversible nature is evidenced by the criteria: The $\Delta \mathrm{Ep}$ increases with increasing scan rate $(10,50,100,150$ and $200 \mathrm{mV} / \mathrm{s}){ }^{35-37}$ The value of $\Delta \mathrm{Ep}$ is more than $59 \mathrm{mV}$, which also indicates quasi-reversible redox process.

The peak potential dependency on scan rates indicates simply one electron transfer. Further, the plots of Current $(\mu \mathrm{A})$ against Scan rate were found to be linearly shown in Fig.-6. indicating that the redox process was controlled by diffusion following the Randles-Sevcik equation for reversible electrochemical reactions.

Table-6: Cyclic Voltammetric Data of Ligand (L) and its Complexes 4 and 5.

\begin{tabular}{c|c|c|c|c|c|c}
\hline S. No. & Complex & Scan rate & Epa & Epc & $\begin{array}{c}\Delta \text { Ep } \\
(\mathrm{mv})\end{array}$ & $\mathrm{E}_{1 / 2}$ \\
\hline 1 & $\mathrm{~L}$ & 0.01 & 0.7568 & 0.7324 & 0.02442 & 0.7446 \\
\hline 2 & $\mathrm{~L}$ & 0.05 & 1.0303 & 0.8252 & 0.2051 & 0.9277 \\
\hline 3 & $\mathrm{~L}$ & 0.1 & 1.1304 & 0.8789 & 0.25149 & 1.0046 \\
\hline 4 & $\mathrm{~L}$ & 0.15 & 1.2012 & 0.8813 & 0.31985 & 1.0412 \\
\hline 5 & 4 & 0.01 & 1.0181 & 0.9619 & 0.11909 & 0.9900 \\
\hline 6 & 4 & 0.05 & 1.3061 & 1.0327 & 0.2734 & 1.1694 \\
\hline 7 & 4 & 0.1 & 1.3566 & 1.0522 & 0.3044 & 1.2044 \\
\hline 8 & 4 & 0.15 & 1.5259 & 1.1987 & 0.3272 & 1.3623 \\
\hline 9 & 5 & 0.01 & 0.9505 & 0.8434 & 0.1071 & 0.8969 \\
\hline 10 & 5 & 0.05 & 1.0899 & 0.8607 & 0.229 & 0.9753 \\
\hline 11 & 5 & 0.1 & 1.1841 & 0.9147 & 0.2694 & 1.0494 \\
\hline 12 & 5 & 0.15 & 1.2969 & 0.9415 & 0.3554 & 1.1192 \\
\hline
\end{tabular}


RASĀYAN J. Chem.

Vol. 12 | No. 1 |101 - 113| January - March | 2019

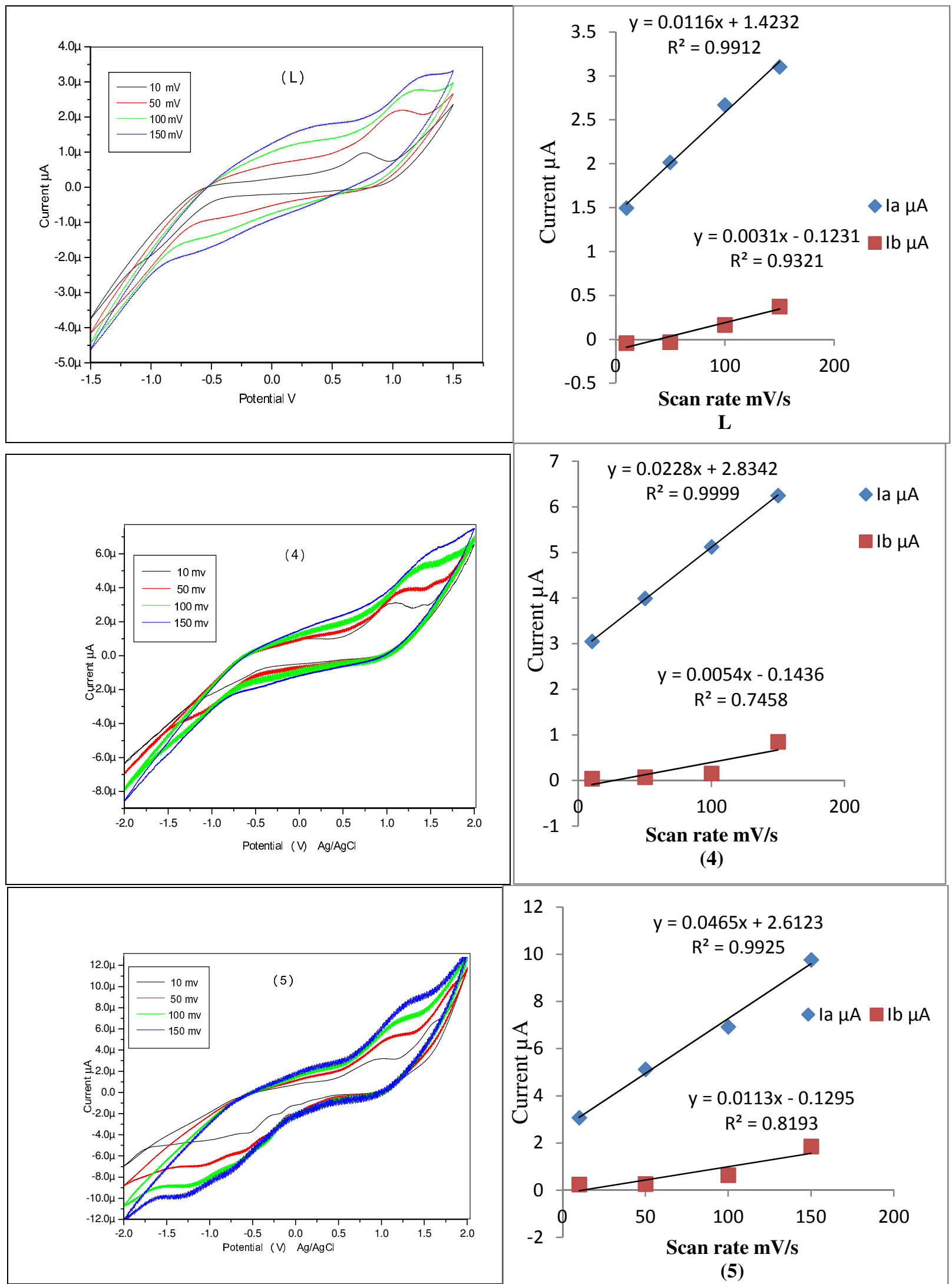

Fig.- 6: CV and Linear Plot of Peak Current Vs Scan Rate of Ligand (L) and its Complex 4=[Ni(L) $\left.{ }_{2}\right]\left(\mathrm{H}_{2} \mathrm{O}\right)_{2}$, and $5=\left[\mathrm{Cu}(\mathrm{L})_{2}\right]\left(\mathrm{H}_{2} \mathrm{O}\right)_{2}$. 
RASĀYAN J. Chem.

Vol. 12 | No. 1 |101 - 113| January - March | 2019

\section{CONCLUSION}

The $\beta$-diketones 3-hydroxy-3-(2-hydroxyphenyl)-1-(2-iodo-5-methyl phenyl)prop-2-en-1-one have been synthesized from Baker-Venkataraman transformation of 2-acetylphenyl 2-iodo-5-methyl benzoate. Their transition metal complexes have been prepared and characterized by physical, spectral and analytical data. The functionalized beta-diketone potentially acts as a bidentate ligand and co-ordinate with the transition metal atom through the beta-diketo system. The complexes have general formula $\left[\mathrm{M}(\mathrm{L})_{2}\right]\left(\mathrm{H}_{2} \mathrm{O}\right)_{2}$ where $\mathrm{M}$ $=\mathrm{Mn}(\mathrm{II}), \mathrm{Fe}(\mathrm{III}), \mathrm{Co}(\mathrm{II}), \mathrm{Ni}(\mathrm{II}), \mathrm{Cu}(\mathrm{II})$ and $\mathrm{L}=$ ligand. Ligand $\mathrm{L}$ and their transition metal complexes have been screened for in vitro antibacterial, anti-inflammatory and antioxidant activities. The biological activity data show that the transition metal complexes are more potent agents than the parent betadiketone. This constitutes a new group of compounds that can be used as potential metal derived drugs.

\section{ACKNOWLEDGMENT}

The Department of Chemistry acknowledges the financial assistance by UGC-SAP-DRS scheme-1. One of the authors Narendra A. Bhise is thankful for the financial assistance from the University Scholar Fellowship, Dr. Babasaheb Ambedkar Marathwada University Aurangabad.

\section{REFERENCES}

1. Z. Lu, L.Yang, J. Inorg. Biochem., 95, 31(2003).

2. J. Z. Wu, H. Li, J. G. Zhang, H. Xu Ju, Inorg. Chem. Commun., 571, (2002).

3. J. D. Lee $5^{\text {th }}$ Eds Concise Inorganic Chemistry. 195, (1996),

4. O. G. Khudina, Y. V. Burgart,N. V. Murashova, V. I. Saloutin, Russian J. Org. Chem., 39, 1421 (2003).

5. G. Aromi, P. G amez and J. Reedijk, Coordination Chemistry Reviews, 252, 964(2008).

6. S. T. Heller, S. R. Natarajan, Org. Lett.,8, 2675(2006).

7. D. Simoni, F. P. Invidiata, R. Rondanin, S. Grimaudo, G. Cannizzo, E. Barbusca, N. A. Porretto, F. D. lessandro, M. Tolomeo, J. Med. Chem., 42, 4961(1999).

8. H. Valizadeh, M. Amiri, E. Khalili, Molecular Diversity, 16(2), 319(2012).

9. L. Tang, S. Zhang, J. Yang, W. Gao, J. Cui, T. Zhuang, Molecules, 9, 842(2004).

10. R. Kumar, Y. C. Joshi, ARKIVOC, 9, 142(2007).

11. O. G. Kuzueva, Y. V.Burgart, V. I.Saloutin, O. N.Chupakhin, 37, 1130(2001).

12. L. Tchertanov, J. F. Mouscadet, J. Med. Chem., 50, 1133(2007).

13. Manuel, A., R. Silva and Luis M. Santos, J. Chem. Thermodynamics, 38, 817 (2005)

14. K. Binnemans, Chem. Rev. 107, 2592(2007).

15. R. Karvembu, K. Natarajan, Polyhedron, 212, 219(2002).

16. Huaqiang Zeng, JianmingXie, P. G. Schultz, Bioinorg. Med. Chem. Let, 16, 5356(2006).

17. Narendra A. Bhise, Shalini T. Dengle, Suresh T. Gaikwad and Anjali S. Rajbhoj Der Pharma Chemica, 8(19), 338(2016).

18. J. Charette, G. Neirynck. P. Teyssie, J. Phys. Chem.65, 735(1961).

19. R. Sultan, K. Gadamsetti, S. Swavey, Inorg. Chim. Acta. 359, 1233(2006).

20. D. Z. Ma, Y. Q. Wu, X. Zuo, Materials. Letters, 59, 3678(2005)

21. R. Gup, B. Kirkan, Spectrochim. Acta Part A, 62, 1188 (2005).

22. Zhimin Chen, Yiqun Wu, Fuxin Huang, Donghong Gu, Fuxi Gan, Spectrochimica Acta Part A, 66, 1024 (2007).

23. K. Nakamoto, Coordination compounds, in: Infrared and Raman Spectra Inorganic and Coordination Compounds, John Wiley, New York, (1976).

24. F. X. Huang, Y. Q. Wu, D. H.Gu, F. X. Gan, Spectrochim. Acta Part A, 61, 2856 (2005).

25. Pavia, Lampman, Kriz, Vyvyan, The Background Spectrum, Spectroscopy (2009).

26. K. R. S. Gowda, H. S. B. Naik, B. V. Kumar, C. N. Sudhamani, H. V. Sudeep. T. R. R. Naik, and G. Krishnamurthy, Spectrochim. Acta Part A, 105, 229(2013).

27. M. Shakir, Summaiya Hanif, Mohd. Asif Sherwani, \& Owais Mohammad, Saud I. Al-Resayes, Journal of Molecular Structure, 1092, 143(2015). 


\section{RASĀYAN J. Chem.}

Vol. 12 | No. 1 |101 - 113| January - March | 2019

28. D. Dinesh, K. Murugan, P. Madhiyazhagan, C. Panneerselvam, P. M. Kumar, M. Nicoletti, W. Jiang, G. Benelli, B. Chandramohan, and U. Suresh, Parasitol. Res., 114(4), 1519(2015).

29. M. Varadarasu, S. Mounisamy, V. Kavimani, S. Balu Darlin Quine, Iranian Journal of Pharmacology and Therapeutics, 11, 235(2007).

30. O. James, O. P. Nnacheta, H. S. Wara, U. R. Aliyu, Int J of Pharmtech Research.,1(3), 474(2009)

31. R. Dery R. Davison A. Befus, International archives of allergy and immunology, 124, 201(2001).

32. B. G. Tweedy, Phytopathology, 55, 910(1964).

33. D. S. Raja, N. S. P. Bhuvanesh, K. Natarajan, Dalton Trans., 41, 4365(2012).

34. R. P. John, A. Sreekanth, V. Rajakannan, T. A. Ajith, M. R. P. Kurup, Polyhedron, 23, 2549(2004).

35. S. Panda, R. Mishra, A. K. Panda, and K. C. Satpathy, J. Indian Chem. Soc., 66, 472(1989).

36. S. H. Zhang, Y. Q. Yang, Y. F. Kuang, Chin. J. Inorg. Chem., 29, 138(2013).

37. Z. M. Chen, Y. Q. Yang, Z. J. Yi Chin. J. Inorg. Chem. 30, 659(2014).

[RJC-4045/2018] 